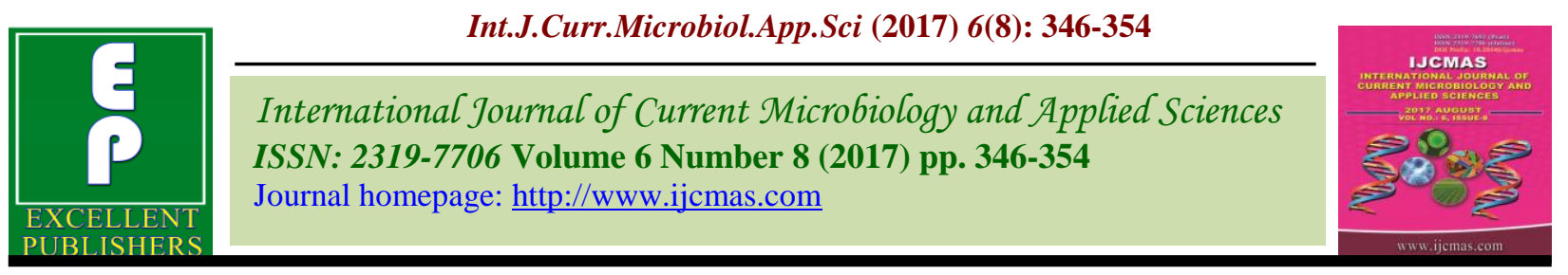

Original Research Article

https://doi.org/10.20546/ijcmas.2017.608.046

\title{
Compatibility Studies of Trichoderma harzianum Isolate with Fungicides used against Soil Borne Disease in Coorg Mandarin-Pepper-Coffee Plantations
}

\section{Priti Sonavane* and Venkataravanappa}

\author{
Central Horticultural Experiment Station, ICAR-IIHR, Chettalli, Kodagu, \\ Karnataka-571248, India \\ *Corresponding author
}

Key w or d s
Trichoderma
species,
Fungicides,
Compatibility,
In vitro.
Article Info
$\begin{aligned} & \text { Accepted: } \\ & \text { 04 June } 2017 \\ & \text { Available Online: } \\ & \text { 10 August } 2017\end{aligned}$

An in vitro bioassay was undertaken to record the compatibility of local isolate of Trichoderma harzianum with fungicides used in coorg mandarin-pepper-coffee plantations. Eight non-systemic, 10 systemic and 9 combi products fungicides were evaluated against Trichoderma for radial growth inhibition on PDA medium using poisoned food technique. Contact fungicides at selected concentration were found to be safer than systemic and combi products except Chlorothalonil. In systemic fungicidal treatments complete mycelial inhibition of $T$. harzianum was recorded in Carbendazim, Hexaconazole, Thiophenate Methyl and Propiconazole. In combi products $T$. harzianum was not compatible with Hexaconazole 4\%+Zineb 68\%, Carbendazim $12 \%+$ Mancozeb $63 \%$, Tebuconazole $50 \%+$ Trifloxystrobin $25 \%$ WG, Pyraclostrobin 133g/l + Epoxiconazole $50 \mathrm{~g} / 1$ and Captan $70 \%+$ Hexaconazole 5\% WP in any level of selected concentrations. Whereas, reduction in sporulation of T. harzianum was recorded in Metalaxyl 4\%Mancozeb 64\% WP and Fenamidone $10 \%$ + Mancozeb 50 WG with increase in concentrations.

\section{Introduction}

Biological plant protection strategies includes using bio-control agents such as antagonists, beneficial micro-organisms etc. Bioagents reduces excessive use and misuse of synthetic fungicide and development of fungicide resistance in pathogen. Combination of fungicides and bioagents together can form an important component in effective and safe disease management strategies. Among the fungal biocontrol agents, Trichoderma spp. has acquired much importance (Papavizas, 1985; Sreenivasaprasad and Manibhushanrao,
1990). Major mechanisms used by Trichoderma against plant pathogens are mycoparasitism, antibiosis and competition nutrient and space and high reproduction rate. Trichoderma has been found to be effective against major soil borne diseases such as pre and post-emergence damping-off, caused by Pythium, Phytophthora and Rhizoctonia species, root rot, stem rot caused by Phytophthora, Sclerotinia, Sclerotium including, vascular wilts caused by Fusarium, Verticillium, and nematodes. In recent period 
Trichoderma is applied to aerial plant parts on disease pruned shrubs and trees, Helminthosporium oryzae causal agent of Brown spot of rice (Mouria et al., 2003), four species of Bipolaris ( $B$. maydis, $B$. sorokiniana, B. sorghicola and B. tetramera) on Sorghum (Berber et al., 2009).

It is therefore important to identify compatibility of potential bioagents with commonly used fungicides. The effect of certain fungicides and herbicides on Trichoderma spp. was reported earlier with an emphasis on practical applications (Kredics et al., 2003). As fungicides should have inhibitory effect on the pathogen but should not have deleterious effect on the antagonists, an understanding of the effect of fungicides on the pathogen and the antagonists would provide information for the selection of fungicides and fungicide resistant antagonists, through compatibility studies in vitro.

In addition, this strategy may display even better control of resistant strains of fungal pathogens and may help the commercial growers to reduce the amount of fungicide use, thus lowering the amount of chemical residue in the marketed products. In this context a study was undertaken to check the compatibility of native Trichoderma sp. with different fungicides used against seed borne diseases, soil borne and foliar diseases.

Kodagu is the thickly wooded grandeur on the Western Ghats covered by forests and Coorg mandarin-pepper-coffee plantation. For Coorg mandarin and pepper large amount of fungicides are used for control of Phytophthora diseases.

A local isolate of Trichoderma harzianum was isolated from the soil samples collected from Kodagu district. This isolate has been used for mass multiplication and distribution to farmers. Based on the studies conducted by Sawant and Sawant, 1989 coffee husk is used as substrate for multiplication. The isolate is majorly used as soil treatment in Coorg mandarin-pepper-coffee plantation. Therefore there was a need to study the compatibility of the isolate with locally available fungicides under in vitro conditions.

\section{Materials and Methods}

\section{Trichoderma species and fungicides}

The fungal isolate used in the present study was isolated from the soils of Coorg mandarin-pepper-coffee based plantation of Chettali, Kodagu district. Standard serial dilution method was followed for isolation of Trichoderma on selective media (Hi media). Plates were incubated at $25 \pm 2^{\circ} \mathrm{C}$ for 5 days. Different Trichoderma colonies appearing on the plates were purified in the Potato Dextrose Agar (PDA).

\section{Fungal genomic DNA purification}

The pure culture of the fungus was grown on Potato Dextrose Broth at $25 \pm 2{ }^{\circ} \mathrm{C}$ for 7 days. The fungal mycelium was harvested by filtration through Whatman No.1 filter paper and washed with sterile distilled water and dried. Two grams of dried mycelium was for total genomic DNA by following modified protocol of CTAB method (RF).

The quality of the genomic DNA was checked on $0.8 \%$ agarose gel and stored at $-20^{\circ} \mathrm{C}$ till further use.

\section{Fungal materials and microscopy}

The pure culture of fungus conidial morphology was examined under the light microscope (Nikon Eclipse 50i). The 12 days old of culture of the fungus was grown PDA were scraped and placed on a glass slide containing a drop of sterile water. The specimen was observed at 400X magnification under a microscope. 


\section{PCR amplification}

To confirm identity of the pathogen, total genomic DNA was amplified by PCR using universal internal transcriber spacer region primers ITS1 (5'-TCCGTAGGTGAACCTG CGG-3') and ITS4 (5'-TCCTCCGCTTATT GATATGC-3') (White et al., 1990). The DNA amplification was performed with 35 cycles with cycling conditions of denaturation for $1 \mathrm{~min}$ at $94^{\circ} \mathrm{C}$, primer annealing for 45 seconds at $55^{\circ} \mathrm{C}$, and primer extension for 90 seconds at $72^{\circ} \mathrm{C}$, with an initial denaturation at $94^{\circ} \mathrm{C}$ for $3 \mathrm{~min}$ and a final extension for 15 min at $72^{\circ} \mathrm{C}$. The PCR reactions were carried out in a Gene Amp PCR system 9700 (PE Applied Biosystems, Foster City, CA) thermocycler. The final volume of $25 \mu \mathrm{L}$ PCR mix containing $2 \mu \mathrm{L}$ DNA template, $1.5 \mathrm{U}$ Taq polymerase, $25 \mathrm{mM} \mathrm{MgCl} 2,2 \mathrm{mM}$ dNTPs and 25 pmole of each primer were taken in a PCR tube. PCR products were electrophoresed ( $1 \mathrm{~h}$ at 80 volts) in $1.2 \%$ agarose gel in Tris-borate-EDTA buffer, $\mathrm{pH}$ 8.0. Gels were stained with ethidium bromide $(10 \mathrm{mg} / \mathrm{mL})$ and were visualized and documented by Alpha digidoc1000 system (Alpha Innotech Corporation, USA). The amplified PCR products (550bp) were purified by gel extraction kit (Qiagen) and sequencing was done by Eurofins Genomics India Pvt. Ltd (Karnataka, India).

\section{Fungicides evaluation}

A random survey was carried out to record various fungicides used in control of Phytophthora wilt in Coorg mandarin-peppercoffee based plantation in different parts of Kodagu district. The fungicides were predominately in control the soil borne Phytophthoradisease were selected for study of compatibility against Trichoderma, which includes eight contacts, ten systemic and nine combi-products fungicides were evaluated by poisoned food technique under in vitro conditions. The fungicides were selected based on the regular usage for management of different soil borne pathogens in Coorg mandarin-pepper-coffee based plantations. The list of fungicides used along with their chemical, trade names and concentration were given in the supplementary table 1 .

\section{Poison food technique}

The poisoned food technique (Shravelle, 1961) was followed to evaluate the efficacy of different systemic, non-systemic and combiproducts fungicides for radial mycelial growth inhibiting of the Trichoderma. Stock solutions of fungicides were prepared by dissolving the required quantities of each fungicide separately in sterile distilled water. The fungicidal suspension was added to the PDA melted medium to obtain the required concentrations on commercial formulation basis of the fungicide. Twenty $\mathrm{ml}$ of poisoned medium was poured in each sterilized Petriplates under aseptic condition. Suitable check was maintained without addition of fungicide. Mycelial disc of $5 \mathrm{~mm}$ was taken from the periphery of seven days old colony of Trichoderma and was placed in the center of Petriplates and incubated at $27 \pm 1^{\circ} \mathrm{C}$ for 12 days and three replications were maintained for each treatment.

Overall experimental design followed was factorial Completely Randomized Design where in fungicides formed the factors and concentration formed the levels. The diameter of the colony was measured in two directions and average growth was recorded. Per cent inhibition of mycelial growth of the fungus was calculated by using the formula given by Vincent (1947) as indicated below.

$$
\begin{aligned}
& \text { I = - - C-T }) \\
& \text { C } \\
& \text { Where, } \\
& \text { I = Per cent inhibition } \\
& \text { C = Radial growth in control }
\end{aligned}
$$


$\mathrm{T}=$ Radial growth in treatment (fungicide/bioagent)

\section{Statistical analysis}

The data obtained in these experiments were statistically analyzed by using completely randomized design (CRD). The data pertaining to percentages were angularly transformed. (Table 2) Results were analyzed by following appropriate statistical methods as per the procedure suggested by Panes and Sukhatme (1978).

\section{Results and Discussion}

\section{Morphological characterization}

Pure culture of pathogen was produced on Potato dextrose agar. On the basis of colony morphology and conidial characters isolate was initially identified as $T$. harzianum. Further to confirm the fungal species, total genomic DNA of T. harzianum was amplified by using universal internal transcriber spacer region (ITS) specific primers. The expected PCR amplicon size of 550bp was amplified (data not shown). The amplified PCR product was cloned and sequenced. The sequence is available in database under following accession numberKU933355. The identified pure culture of $T$. harzianum was used for compatibility study of different fungicides.

\section{In vitro screening of Trichoderma species for tolerance to different fungicides}

In-vitro compatibility test were done with eight contact, ten systemic and nine combiproducts fungicides against tolerance to $T$. harzianum (Table 1). Among the treatments the mean radial growth of $T$. harzianum varied from 0.0 to $9.0 \mathrm{~cm}$ in different fungicides. The result also showed that the contact fungicides (Captan 50WP, Mancozeb 75WP, Zineb 75WP, Sulphur 80WDG and Copper oxychloride 50WP) at selected concentration were found to be safer than systemic and combi products except Chlorothanil 75WP. The contact fungicides are more compatible with $T$. harzianum and luxuriant growth of antagonist was found in all the petriplates containing poisoned medium and the observed maximum radial growth of $T$. harzianum inall fungicides except Chlorothanil 75WP followed by Dinocap 48 EC (Figure 1).

The Incorporation of systemic fungicides in growth medium did not affect the growth of Trichoderma spp. instead fungicides favoured the growth of fungi at the concentrations of 100 to1000 ppm compared to control. However some systemic fungicides (Carbendazim, Hexaconazole, Thiophenate Methyl and Propiconazole) completely inhibited mycelia growth of $T$. harzianumat the concentrations of 250 to $1000 \mathrm{ppm}$ compared to control. Similarly in combiproducts significant difference in mycelial growth inhibition and sporulation was observed at all concentration.

At lower concentration (500ppm) of the fungicides Metiram $55 \%+$ Pyraclostrobin 5 $\%$ WG, Metalaxyl $8 \%+$ Mancozeb $64 \%$ WP, Metalaxyl 4\%-Mancozeb 64\% WP and Fenamidone $10 \%$ + Mancozeb 50 WG) recorded good radial mycelial growth, But there was decrease in radial mycelial growth gradually as well as sporulation with an increase in concentration of Metalaxyl 4\%Mancozeb 64\% WP (500-2000 ppm) and Fenamidone $10 \%$ + Mancozeb 50 WG) (5002000 ppm), whereas other fungicides (Hexaconazole 4\%+Zineb 68\%, Carbendazim $12 \%+$ Mancozeb $63 \%$, Tebuconazole $50 \%$ + Trifloxystrobin $25 \%$ WG, Pyraclostrobin 133g/l + Epoxiconazole $50 \mathrm{~g} / \mathrm{l}$ and Captan $70 \%+$ Hexaconazole 5\% WP) which are completely inhibiting the radial growth of $T$. harzianum are at all selected level of concentrations (500-2000ppm). 
Table.1 Effect of contact, systemic and combi fungicides used in Coorg mandarin-pepper-coffee plantations on the Mycelial growth of Trichoderma harzianum

(A) Contact Fungicides

\begin{tabular}{|c|c|c|c|c|c|}
\hline \multirow{2}{*}{$\begin{array}{c}\text { Chemical name } \\
\text { Concentration (ppm) }\end{array}$} & \multicolumn{4}{|c|}{ Mycelial inhibition (\%) } & \multirow{2}{*}{$\begin{array}{c}\text { Compatible/ Non } \\
\text { compatible }\end{array}$} \\
\hline & 500 & 1000 & 1500 & 2000 & \\
\hline Captan 50 & $0.00(0.00)$ & $0.00(0.00)$ & $5.88(8.28)$ & $24.31(24.73)$ & $\mathrm{C}$ \\
\hline Mancozeb 75WP & $0.00(0.00)$ & $0.00(0.00)$ & $0.00(0.00)$ & $5.88(11.36)$ & $\mathrm{C}$ \\
\hline Zineb 75WP & $0.00(0.00)$ & $0.00(0.00)$ & $0.00(0.00)$ & $0.00(0.00)$ & $\mathrm{C}$ \\
\hline Chlorothalonil 75WP & $76.08(60.80)$ & $86.27(68.32)$ & $87.15(69.00)$ & $85.56(67.86)$ & $\mathrm{N}$ \\
\hline Dinocap 48 EC & $13.72(21.70)$ & $21.56(27.57)$ & $36.02(36.86)$ & $36.19(36.97)$ & $\mathrm{C}$ \\
\hline Sulphur 80WDG & $0.00(0.00)$ & $0.00(0.00)$ & $0.00(0.00)$ & $7.76(16.02)$ & $\mathrm{C}$ \\
\hline Mancozeb 75 WP & 0.000 .00 & $0.00(0.00$ & $0.00(0.00$ & $0.00(0.00$ & $\mathrm{C}$ \\
\hline Copper oxychloride 50WP & $0.00(0.00)$ & $0.00(0.00)$ & $0.00(0.00)$ & $0.00(0.00)$ & $\mathrm{C}$ \\
\hline $\mathrm{CD}$ & 2.497 & 2.686 & 8.946 & 15.099 & \\
\hline $\mathrm{SE}(\mathrm{d})$ & 1.168 & 1.256 & 4.184 & 7.062 & \\
\hline $\mathrm{SE}(\mathrm{m})$ & 0.826 & 0.888 & 2.958 & 4.993 & \\
\hline $\mathrm{CV}$ & 13.871 & 12.838 & 35.916 & 44.088 & \\
\hline
\end{tabular}

(B) Systemic Fungicides

\begin{tabular}{|c|c|c|c|c|c|}
\hline \multirow{2}{*}{$\begin{array}{c}\text { Chemical name } \\
\text { Concentration (ppm) }\end{array}$} & \multicolumn{4}{|c|}{ Mycelial inhibition (\%) } & \multirow{2}{*}{$\begin{array}{c}\text { Compatible/ Non } \\
\text { compatible }\end{array}$} \\
\hline & 250 & 500 & 750 & 1000 & \\
\hline Fosetyl-al $80 \% \mathrm{WP}$ & $0.00(0.00)$ & $0.00(0.0)$ & $0.00(0.00)$ & $0.00(0.00)$ & $\mathrm{C}$ \\
\hline Azoxystrobin $23.00 \% \mathrm{~W} / \mathrm{W}$ & $0.00(0.00)$ & $0.00(0.0)$ & $0.00(0.00)$ & $0.00(0.00)$ & $\mathrm{C}$ \\
\hline Carbendazim $50 \% \mathrm{WP}$ & $100.00(90.00)$ & $100.00(90.0)$ & $100.00(90.00)$ & $100.00(90.00)$ & $\mathrm{N}$ \\
\hline Tricyclozole $75 \% \mathrm{WP}$ & $0.00(0.00)$ & $0.00(0.0)$ & $0.00(0.00)$ & $0.00(0.00)$ & $\mathrm{C}$ \\
\hline Hexaconazole $5 \%$ & $60.95(51.32)$ & $100.00(90.0)$ & $100.00(90.00)$ & $100.00(90.00)$ & $\mathrm{N}$ \\
\hline Pyraclostrobin $20 \% \mathrm{WG}$ & $0.00(0.00)$ & $0.00(0.0)$ & $0.00(0.00)$ & $0.00(0.00)$ & $\mathrm{C}$ \\
\hline Thiophenate Methyl $70 \%$ WP & $63.46(52.79)$ & $100.00(90.0)$ & $100.00(90.00)$ & $100.00(90.00)$ & $\mathrm{N}$ \\
\hline Metalaxyl $35 \%$ WS & $0.00(0.00)$ & $0.00(0.0)$ & $0.00(0.00)$ & $10.58(18.71)$ & $\mathrm{C}$ \\
\hline Triademefon $25 \% \mathrm{WP}$ & $0.00(0.00)$ & $1.93(4.6)$ & $3.87(9.29)$ & $6.80(15.09)$ & $\mathrm{C}$ \\
\hline Propiconazole $25 \%$ EC & $100.0090 .00)$ & $100.00(90.0)$ & $100.00(90.00)$ & $100.00(90.00)$ & $\mathrm{N}$ \\
\hline $\mathrm{CD}$ & 1.601 & 4.362 & 4.362 & 2.33 & \\
\hline $\mathrm{SE}(\mathrm{d})$ & 0.762 & 2.077 & 2.077 & 1.109 & \\
\hline $\mathrm{SE}(\mathrm{m})$ & 0.539 & 1.468 & 1.468 & 0.784 & \\
\hline $\mathrm{CV}$ & 3.286 & 6.975 & 6.887 & 3.45 & \\
\hline
\end{tabular}


(C) Combi Fungicides

\begin{tabular}{|c|c|c|c|c|c|}
\hline \multirow{2}{*}{$\begin{array}{c}\text { Chemical name } \\
\text { Concentration (ppm) }\end{array}$} & \multicolumn{4}{|c|}{ Mycelial inhibition (\%) } & \multirow[t]{2}{*}{$\begin{array}{c}\text { Compatible/ } \\
\text { Non compatible }\end{array}$} \\
\hline & 500 & 1000 & 1500 & 2000 & \\
\hline $\begin{array}{c}\text { Hexaconazole } 4 \%+\text { Zineb } \\
68 \%\end{array}$ & $94.90(82.32)$ & $100.00(90.00)$ & $94.12(81.71)$ & $100.00(90.00)$ & $\mathrm{N}$ \\
\hline $\begin{array}{c}\text { Metiram 55 \%+ } \\
\text { Pyraclostrobin 5\% WG }\end{array}$ & $0.00(0.00)$ & $0.00(0.00)$ & $0.00(0.00)$ & $0.00(0.00)$ & $\mathrm{C}$ \\
\hline $\begin{array}{c}\text { Carbendazim } 12 \%+ \\
\text { Mancozeb } 63 \%\end{array}$ & $100.00(90.00)$ & $100.00(90.00)$ & $100.00(90.00)$ & $100.00(90.00)$ & $\mathrm{N}$ \\
\hline $\begin{array}{c}\text { Metalaxyl } 8 \%+\text { Mancozeb } \\
64 \% \mathrm{WP}\end{array}$ & $0.00(0.00)$ & $0.00(0.00)$ & $0.00(0.00)$ & $0.00(0.00)$ & $\mathrm{C}$ \\
\hline $\begin{array}{c}\text { Tebuconazole } 50 \%+ \\
\text { Trifloxystrobin } 25 \% \mathrm{WG}\end{array}$ & $100.00(90.00)$ & $100.00(90.00)$ & $100.00(90.00)$ & $100.00(90.00)$ & $\mathrm{N}$ \\
\hline $\begin{array}{l}\text { Pyraclostrobin } 133 \mathrm{~g} / \mathrm{l}+ \\
\text { Epoxiconazole } 50 \mathrm{~g} / 1\end{array}$ & $100.00(90.00)$ & $100.00(90.00)$ & $100.00(90.00)$ & $100.00(90.00)$ & $\mathrm{N}$ \\
\hline $\begin{array}{c}\text { Metalaxyl 4\%-Mancozeb } \\
64 \% \mathrm{WP}\end{array}$ & $3.89(9.32)$ & $13.72(21.64)$ & $17.01(24.34)$ & $18.99(25.81)$ & $\mathrm{C}$ \\
\hline $\begin{array}{c}\text { Fenamidone } 10 \%+ \\
\text { Mancozeb } 50 \mathrm{WG}\end{array}$ & $13.72(21.64)$ & $9.77(18.01)$ & $13.72(21.70)$ & $15.68(23.23)$ & $\mathrm{C}$ \\
\hline $\begin{array}{c}\text { Captan } 70 \%+ \\
\text { Hexaconazole } 5 \% \mathrm{WP}\end{array}$ & $100.00(90.00)$ & $100.00(90.00)$ & $100.00(90.00)$ & $100.00(90.00)$ & $\mathrm{N}$ \\
\hline $\mathrm{CD}$ & 9.109 & 2.582 & 8.333 & 1.714 & \\
\hline $\mathrm{SE}(\mathrm{d})$ & 4.302 & 1.22 & 3.936 & 0.809 & \\
\hline $\mathrm{SE}(\mathrm{m})$ & 3.042 & 0.862 & 2.783 & 0.572 & \\
\hline $\mathrm{CV}$ & 10.02 & 2.746 & 8.894 & 1.788 & \\
\hline
\end{tabular}

* Figures in parenthesis are Arc sign transformed values 
Fig.1 Effect of contact, systemic and combi fungicides used in Coorg mandarin-pepper-coffee plantations on the mycelial growth of Trichoderma harzianum
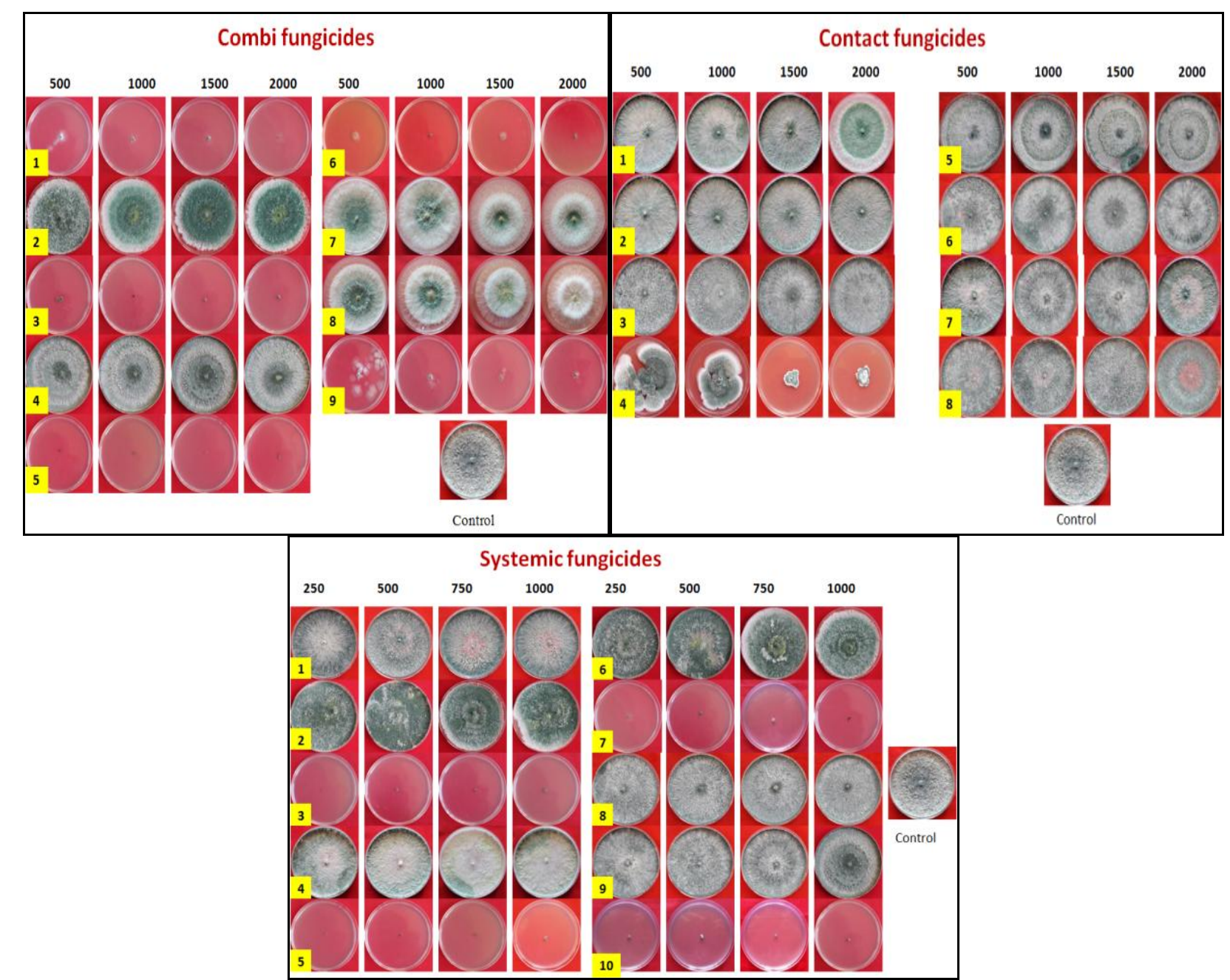

Contact fungicides: 1. Captan, 2. Mancozeb, 3. Zineb, 4. Chlorothalonil, 5. Dinocap, 6. Sulphur, 7. Mancozeb, 8. COC. Systemic fungicides: 1. Fosetyl-al, 2. Azoxystrobin, 3. Carbendazim, 4. Tricyclozole, 5. Hexaconazole, 6. Pyraclostrobin, 7. Thiophenate Methyl, 8. Metalaxyl, 9. Triademefon, 10. Propiconazole.Combi products: 1. Hexaconazole 4\%+Zineb 68\%, 2. Metiram $55 \%$ + Pyraclostrobin $5 \%$, 3. Carbendazim $12 \%$ + Mancozeb 63\%, 4. Metalaxyl 8\% + Mancozeb $64 \%, 5$. Tebuconazole $50 \%+$ Trifloxystrobin 25 $\%$, 6. Pyraclostrobin 133g/l + Epoxiconazole, 7. Metalaxyl 4\%-Mancozeb 64\%, 8. Fenamidone $10 \%$ + Mancozeb 50, 9. Captan $70 \%+$ Hexaconazole 5\%; All the concentration are in $\mathrm{ppm}$ 
In the present study, laboratory experiments were conducted to observe the compatibility of Trichoderma species with fungicides. The results revealed that at a selected concentration contact fungicides were safer than systemic and combi products. The literatures suggest that bio control agents that can tolerate a certain level of fungicides were mixed with agrochemicals, resulting in eradication of diseases (De Cal et al., 1994). Similarly Thiram $(0.2 \%)$, COC $(0.2 \%)$ and Mancozeb $(0.2 \%)$, Captaf $(0.2 \%)$ and Blue copper $(0.2 \%)$ are compatibility with Trichoderma harzianum, whereas the fungicides viz; Carbendazim and Thiophanate methyl was completely inhibiting the mycelia growth Trichoderma harzianum at 0.1-0.2\% concentration respectively (Gowdar et al., 2006). Ramarethinam et al., (2001) reported that the fungicides like Carbendazim $(50 \%$ WP), Hexaconazole (5\% EC) completely inhibited the growth of Trichoderma viridein vitro. Desai and Srikant, (2002) also reported that Mancozeb at $500 \mathrm{ppm}$ recorded a lower inhibition of hyphae $(5.70 \%)$ and sporulation (11.02\%) of Trichoderma harzianum. The results are also in agreement with the works of Mukhopadyay et al., (1987) Sharma and Mishra, (1995) who also found good growth of Trichoderma isolates at low and medium concentrations of various fungicides. Among fungicides, Captaf, Thiram, Chlorothalonil and Copper hydroxide were found compatible with the test antagonist up to $100 \mu \mathrm{g}$ a.i. $/ \mathrm{ml}$, while Mancozeb up to $250 \mu \mathrm{g}$ a.i. $/ \mathrm{ml}$, as these did not adversely affect the growth of test antagonist. However, Benomyl, Thiophanate methyl, Bayleton and Ipridione were found incompatible with the test antagonist even at $25 \mu \mathrm{g}$ a.i. /ml (Saxena et al., 2014). Present findings indicated that revealed that seed treatment or soil application of Trichoderma could be exploited along with compatible fungicides at their lower concentrations under bio-intensive integrated disease management practices. The isolate Trichoderma harzianum was found compatible with most of the tested contact fungicides at selected concentration except Chlorothanil. The high incompatibility was observed in the treatments of systemic fungicides (Carbendazim, Hexaconazole, Thiophenate Methyl and Propiconazole) and combi-products (Hexaconazole 4\%+Zineb $68 \%$, Carbendazim $12 \%+$ Mancozeb $63 \%$, Tebuconazole $50 \%+$ Trifloxystrobin $25 \%$ WG, Pyraclostrobin 133g/l + Epoxiconazole $50 \mathrm{~g} / 1$ and Captan $70 \%+$ Hexaconazole 5\% WP) at all concentration respectively. The studies determine the compatibility of Trichoderma and agrochemicals in integrated disease management of various crops under green house and field conditions.

\section{References}

Berber, R.C., Giles, K.L., Zarrabi, A.A. and Payton, M.E. 2009. Development, reproduction, and within-plant infestation patterns of Aphis craccivora (Homoptera: Aphididae) on alfalfa. Environ. Entomol., 38: 1765-1771.

De Cal, A. Pascual, S. Melgarejo, P. 1994.In vitrostudies on the effects of fungicides on beneficial fungi of peach twig mycoflora. Mycopathologia 126: 15-20.

Desai, S.A. and Srikant, K. 2002. Fungistatic effect of Chlorpyriphos on the growth of Trichoderma viride Pers. Karnataka J. Agri. Sci., 15(2): 384-385.

Gowdar, S.B. Babu, H.N.

Nargund, V.B. Krishnappa, M. 2006. Compatibility of fungicides with Trichoderma harzianum. Agric. Sci. Digest Year, 26 (4):279- 281.

Kredics, L. Zsuzsanna, A. László, M. András, S. Ferenc, K. and Erzsébet, N. 2003. Trichoderma Strains with biocontrol potential. Food Technol. Biotechnol, 41 (1) $37-42$.

Mouria A., Ouazzani, T. A. Douira, A. 2003. Etude de certains facteurs favorisant le 
maintien de l'activité antagoniste de Trichoderma harzianum à l'égard de Helminthosporiumoryzae sur les feuilles de riz. Cah Rech. Univ. Hassan II Casablanca, sér. A (Sciences ET Techniques), 5: 50-66.

Mukhopadyay, A.N. 1987. Biological control of soil borne plant pathogens by Trichoderma spp. Presidential address delivered at the 9th Annual meeting of the Society of Mycology and Plant Pathology. Indian J. Mycol. and Plant Pathol, 17: 1-10.

Panse, V. G. and Sukhatme, P. V. 1978. Statistical methods for agricultural workers. New Delhi: Indian Council of Agricultural Research.

Papavizas, G.G. 1985. Trichoderma and Gliocladium: Biology, ecology and potential for biocontrol. Ann. Rev. Phytopathology, 23: 23-54.

Ramarethinam, S. Murugesan, N.V. and Marimuthu, S. 2001. Compatibility studies of fungicides with Trichoderma viride used in commercial formulation. Bio-Cure-F. Pestolo. 25(5): 2-6.

Sawant, I.S. and Sawant, S.D. 1989.Coffee fruit skin and cherry husk as substrates for mass multiplication of Trichoderma harzianum as antagonist to citrus Phytophthora. Indian Phytopathology, 42: 336.

Saxena, D. Tewari, A.K. and Dinesh Rai,
2014. The in vitro Effect of Some Commonly Used Fungicides, Insecticides and Herbicides for Their Compatibility with Trichoderma harzianum PBT23, World Appl. Sci. J., 31(4): 444-448.

Sharma, S.D. and Mishra, A. 1995. "Tolerance of Trichoderma harzianum to agrochemicals", In: Abst. Global conference on Advances in Research on Plant Diseases and Their Management. February 12- 17, 1995. Rajasthan College of Agriculture, India, Pp.162.

Sharvelle, E.G., 1961. The nature and use of modern fungicides. Burges Publication Company, Minnedota, USA. Pp. 308.

Sreenivasaprasad S. and Manibhushanrao K., 1990. Biocontrol potential of fungal antagonists Gliocladium virens and Trichoderma longibrachiatum. J. Plant Dis. Prot., 97: 570-571.

Vincent, J.M. 1947. Distortion of fungal hyphae in the presence of certain inhibitors. Nature, 159:850-850.

White, T. J., Bruns, T., Lee, S. and Taylor, J., 1990. Amplification and direct sequencing of fungal ribosomal RNA genes for phylogenetics. In: Innis, M. A., Gelfand, D. H., Sninsky, J. J., and White T. J., (Eds) PCR Protocols: A Guide to Methods and Applications. Academic, New York. pp. 315-322.

\section{How to cite this article:}

Priti Sonavane and Venkataravanappa. 2017. Compatibility Studies of Trichoderma harzianum Isolate With Fungicides Used Against Soil Borne Disease in Coorg Mandarin-Pepper-Coffee Plantations. Int.J.Curr.Microbiol.App.Sci. 6(8): 346-354. doi: https://doi.org/10.20546/ijcmas.2017.608.046 